\title{
Beta-glucan Content, Antioxidant and Antimicrobial Activities of Some Edible Mushroom Species
}

\author{
Özge Özcan ${ }^{1, *}$, Figen Ertan $^{2}$ \\ ${ }^{1}$ Vocational College of Health Services, Kırklareli University, Kırklareli, Turkey \\ ${ }^{2}$ Department of Biology, Edirne, Faculty of Science, Trakya University, Turkey
}

Copyright $\bigcirc 2018$ by authors, all rights reserved. Authors agree that this article remains permanently open access under the terms of the Creative Commons Attribution License 4.0 International License

\begin{abstract}
In this study the $\beta$-glucan content, antioxidant and antimicrobial activities of Boletus edulis, Cantharellus cibarius, Craterellus cornucopioides, Hydnum repandum and Agaricus bisporus were studied. For this purpose, methanol and acetone extracts of mushrooms were obtained. The $\beta$-glucan content of mushrooms varied between $14.57 \pm 0.80 \%-11.26 \pm$ $0.69 \%$. According to the results obtained from the 2,2-diphenyl-1- picrylhydrazyl (DPPH) assay, the radical scavenging activity was highest in $B$. edulis and $A$. bisporus. The total phenolic content of extracts ranged between $22.75 \pm 0.32-45.5 \pm 0.71 \mu \mathrm{g} / \mathrm{mg}$ as gallic acid equivalents. Mushroom extracts had low reducing power capacity in comparison to standards. When the guaiacol peroxidase activity of mushrooms was examined, $B$. edulis and $A$. bisporus showed enzyme activities of $0.07 \mathrm{U} / \mathrm{ml}$ and $0.13 \mathrm{U} / \mathrm{ml}$, respectively. The antimicrobial activity of acetone and methanol extracts of mushrooms showed varied levels of inhibitory effects on the microorganisms tested.
\end{abstract}

Keywords Mushroom, Antimicrobial, Antioxidant, $\beta$-glucan

\section{Introduction}

Mushrooms have been utilized for medicinal purposes as well as being consumed as food in many parts of the world for centuries. Mushrooms are food sources that are poor in fat while being quite rich in protein, dietary fibre, vitamins and minerals [1]. In the structure of the mushrooms, some minerals such as calcium, phosphorus, potassium, iron, copper are found apart from thiamine, riboflavin, niacin, biotin, cobalamin, ascorbic acid, vitamin D and K [2]. In addition to their high nutrition content, mushrooms are rich in bioactive metabolites such as lecithin, polysaccharide, phenolic and polyphenolic compounds, polyketides, terpenoids, glycopeptides, saponin and ergosterol with high medicinal value [3, 4]. Along with the immunomodulatory and antitumour effects of the mushrooms, it is known that they have antioxidant, antihypertensive, cholesterol lowering, blood glucose regulating, antiallergic, hypolipidemic, antiviral, antimicrobial, hepatic tissue protecting and antifibrotic characteristics $[5,6]$. Some species of mushrooms have been proven to have antitumour effects [7, 8]. The antitumour compounds clavacin, volvotoksin, flammutoksin, lentinan and porisin are isolated only from mushrooms [5].

The most outstanding molecules among the compounds in the structure of mushrooms are the $\beta$-glucans. $\beta$-glucan is a polysaccharide in the fungal cell wall, displaying a $\beta(1 \rightarrow 3)$ linkage and may display $\beta(1 \rightarrow 6)$ branching. It is found in cereals, bacteria and mushrooms. $\beta$-glucan has effects on immune system activation as well as antimicrobial, antioxidant, antiviral, antifungal, antitumour, cholesterol lowering, and blood glucose regulation effects [7].

Mushrooms synthesise secondary metabolites such as phenolic compounds, polyketides, terpenes, and steroids. These secondary metabolites, particularly phenolic compounds found inside the mushroom, have strong antioxidant activities. Phenolic compounds function in metal chelation, free radical scavenging and lipid peroxidation inhibition. Thanks to these antioxidant effects, mushrooms are effective treatments for many ailments, especially cancer and cardiac disease [9].

Various antimicrobial compounds isolated from both mycelium and fruiting bodies of mushrooms have been reported. These secondary metabolites function just like antibiotics. Mushrooms need these antibiotics and vitamins to vegetate and reproduce. Synthetic antibiotics and antimicrobial medicines both threaten human health and cause antibiotic resistance. For this reason, new natural antimicrobial substances obtained from nature are necessary. In this respect, mushrooms are important organisms. Along with antibiotics, $\beta$-glucan in fungal cell 
walls has been determined to have an antimicrobial effect [10].

The aim of this study was to determine the antimicrobial activities and $\beta$-glucan content of four different edible wild mushroom species that grow naturally in the Trakya Region of Turkey and to compare them with a cultured mushroom. Mushrooms were studied in the fresh form as eaten in salads, meals and canned food.

\section{Materials and Methods}

\subsection{Mushrooms}

The edible mushroom species were Boletus edulis (bolet mushroom), Cantharellus cibarius (chanterelle), Craterellus cornucopioides (trumpet mushrooms) and Hydnum repandum (anchusa mushrooms). The cultured mushroom studied was Agaricus bisporus. Mushrooms were provided and identified by Vize Mushroom Food and Agricultural Products Marketing Industry and Trade Limited Company and Akya Mushroom Limited Company. Mushroom samples were obtained fresh and stored at $-20^{\circ} \mathrm{C}$ until analysis.

\subsection{Preparation of Mushroom Extract}

Mushrooms stored at $-20^{\circ} \mathrm{C}$ were allowed to stand at room temperature to thaw. $100 \mathrm{~g}$ of fresh mushroom and $400 \mathrm{ml}$ solvent (acetone or methanol) were homogenized and stirred overnight. The mixture was incubated for 24 hours in a $25^{\circ} \mathrm{C}$ water bath with shaking at $120 \mathrm{rpm}$. After 24 hours the homogenate was filtered through Whatman No. 1 filter paper and the filtrate was stored in the dark. The same process was repeated on the 2 nd and 3 rd days by adding $300 \mathrm{ml}$ solvent to the remaining mushroom sediment in Whatman paper. After three days, samples were treated with $1 / 10$ solvent. Supernatants were collected and the solvent was evaporated in the evaporator at $35^{\circ} \mathrm{C}$. Obtained extracts were stored at $4^{\circ} \mathrm{C}$ until use. Although $\beta$-glucan content determination was made with fresh mushroom, antioxidant activity and antimicrobial activity assays made with extracts [11].

\subsection{Determination of $\beta$-glucan Content}

$\beta$-glucan content determination of the mushroom species was made with fresh mushrooms which milled $<1 \mathrm{~mm}$. To determine the $\beta$-glucan content a "Mushroom and Yeast $\beta$-glucan K-YBGL 8.4" kit was used [12].

\subsection{Antioxidant Activity}

\subsubsection{Determination of DPPH radical scavenging activity}

The free radical scavenging activity of 2,2-diphenyl-1picrylhydrazyl (DPPH) radical was determined using the method of Blois (1958) [13]. In this method, each extract was prepared at 5 different concentrations from 100-1000 $\mu \mathrm{g} / \mathrm{ml} .1 \mathrm{ml}$ from the different concentrations of these extracts was mixed with $4 \mathrm{ml}$ of $0.1 \mathrm{mM}$ DPPH and vortexed. After standing for 30 minutes in the dark, the absorbance was measured at $517 \mathrm{~nm}$. Each sample was measured in triplicate. Ethanol and methanol were used as negative controls and butylated hydroxytoluene (BHT) and butylated hydroxyanisole (BHA) as positive controls.

The \% DPPH radical scavenging activity was calculated using the formula:

$$
\begin{aligned}
& \text { \%DPPH radical scavenging activity } \\
& =\frac{\text { Control absorbance }- \text { sample absorbance }}{\text { control absorbance }} \times 100
\end{aligned}
$$

The concentration by which a substance inhibits $50 \%$ of the DPPH is expressed as IC50 [14]. The IC50 values were calculated from the graph obtained from $\%$ free radical removal activity values against different concentrations studied.

\subsubsection{Determination of total phenolic compounds}

The total phenolic content soluble in methanol and acetone extracts of mushrooms was determined using Folin Ciocalteu Reagent (FCR) [15]. From each sample $1 \mathrm{mg} / \mathrm{ml}$ was mixed with $45 \mathrm{ml}$ water and $1 \mathrm{ml}$ of Folin-Ciocalteu Reagent. After standing for 3 minutes, $3 \mathrm{ml}$ of $2 \% \mathrm{Na}_{2} \mathrm{CO}_{3}$ was added. After vortexing, the mixture was centrifuged at $250 \mathrm{rpm}$ for 2 hours at room temperature. Absorbance was measured at $760 \mathrm{~nm}$. In this study $50-500 \mu \mathrm{g} / \mathrm{ml}$ concentrations of gallic acid were used as the standard.

\subsubsection{Determination of reducing power capacity}

Reducing power was analysed using the Oyaizu (1986) method [16]. $1 \mathrm{ml}$ was taken from each extract sample prepared at $100-1000 \mu \mathrm{g} / \mathrm{ml}$ concentrations and mixed with $2.5 \mathrm{ml} 0.2 \mathrm{M}$ pH6.6 phosphate buffer and $2.5 \mathrm{ml}$ of $1 \%$ $\mathrm{K}_{3} \mathrm{Fe}(\mathrm{CN})_{6}$. The mixture was incubated for 20 minutes at $50^{\circ} \mathrm{C}$. After incubation, $1 \mathrm{ml}$ of sample was taken from the mixture and was mixed with $1 \mathrm{ml}$ of distilled water and 0.2 $\mathrm{ml}$ of $1 \% \mathrm{FeCl} 3$, absorbance values were measured at 700 $\mathrm{nm}$ relative to a reagent blank.

\subsubsection{Guaiacol peroxidase enzyme activity}

Singh's method was used to determine the guaiacol peroxidase enzyme activity of mushroom species. According to the method, reaction mixtures were prepared for samples and for controls. $(1.25 \mathrm{ml}$ of $50 \mathrm{mM}$ Potassium phosphate buffer $\mathrm{pH} 7.0,0.5 \mathrm{ml}, 1 \%$ Guaiacol $0.5 \mathrm{ml}, 0.5$ $\mathrm{ml} 30 \%$ Hydrogen peroxide, $0.1 \mathrm{ml}$ filtered mushroom homogenate for enzyme extract) [17]. After preparation of reaction mixtures, absorbance of the samples was measured with a UV spectrophotometer at $470 \mathrm{~nm}$ every 60 seconds for 4 minutes (1 Enzyme unit: Amount of enzyme that transforms $1 \mu \mathrm{mol}$ guaiacol.) $(\varepsilon=26.6 \mathrm{Mm}-1 \mathrm{~cm}-1)$. 


\subsection{Antimicrobial Activity}

\subsubsection{Test microorganisms}

Test microorganisms used in our study were obtained from Trakya University Faculty of Pharmacy, Department of Pharmaceutical Microbiology Culture Collection and Kirklareli State Hospital Microbiology Laboratory. Pseudomonas aeruginosa ATCC 27853, Pseudomonas aeruginosa clinical isolate, Escherichia coli ATCC 25922, Escherichia coli clinical isolate, Enterococcus faecalis ATCC 29212, Enterococcus faecalis clinical isolate, Staphylococcus aureus ATCC 29213, Staphylococcus aureus clinical isolate, Klebsiella pneumoniae clinical isolate, Serratia marcescens clinical isolate, Candida albicans ATCC 10231, Candida albicans clinical isolates.

\subsubsection{Antibacterial assay}

Antimicrobial activity was determined by the disk diffusion method. 50, 100 and $200 \mathrm{mg} / \mathrm{ml}$ concentrations were prepared by dissolving methanol and acetone extracts obtained from mushrooms in dimethyl sulfoxide (DMSO) and sterilizing by passage through a Chromafil Xtra PTFE-45 filter. The general media, Mueller Hinton Agar, was used for replication of test organisms. After preparation and sterilization in required amounts, media was poured into $90 \mathrm{~mm}$ petri dishes up to $12.5 \mathrm{ml} /$ plate. 6 $\mathrm{mm}$ discs prepared using Whatmann No:1 paper were sterilized. Test microorganism cultures incubated for 24 hours were adjusted to a cell density of $1.5 \times 108 \mathrm{CFU} / \mathrm{ml}$ as per 0.5 McFarland Standard and $100 \mu \mathrm{l}$ was taken and spread on prepared media. Blank discs were impregnated with $10 \mu \mathrm{l}$ of extract and were placed at certain points within the petri dish. $100 \%$ DMSO was used as negative control. Ampicillin $10 \mu \mathrm{g}$, chloramphenicol $10 \mu \mathrm{g}$ and ofloxacin $5 \mu \mathrm{g}$ antibiotic disks were used as positive controls. The petri dishes were stored at $4^{\circ} \mathrm{C}$ for 2 hours to achieve absorption, and then incubated at $37^{\circ} \mathrm{C}$ for 24 hours. Antimicrobial activities of the extracts were determined by measuring the diameter of the resulting zones of inhibition [6].

\subsubsection{Minimum inhibitory concentration}

Minimum Inhibitory Concentrations of mushroom species (MICs) were determined using the microdilution method. According to this method, Mueller-Hinton Broth and Sabouraud Dextrose Broth media was prepared and sterilized and distributed to 96-well micro plates containing $100 \mu \mathrm{l} /$ plate under sterile conditions. $100 \mu \mathrm{l}$ of 4 $\mathrm{mg} / \mathrm{ml}$ extract was added to the first column of the microplates. By performing two-fold dilutions of extracts, concentrations were adjusted to $0.98-2000 \mu \mathrm{g} / \mathrm{ml}$. Test bacteria cultured on Mueller Hinton Agar for 24 hours, were adjusted according to $0.5 \mathrm{McF}$ arland turbidity. The bacterial suspension was diluted 1:100 in order to achieve a final concentration of $105 \mathrm{CFU} / \mathrm{ml}$. The cell concentration of yeast suspensions was adjusted to $2.5 \times 103 \mathrm{CFU} / \mathrm{ml}$ by first diluting 1:50, then 1:20. $10 \mathrm{ml}$ of microorganisms was added to each well. DMSO was added instead of extract as a negative control. As a positive control $1 \mathrm{mg} / \mathrm{ml}$ ampicillin and $2 \mathrm{mg} / \mathrm{ml}$ ciprofloxacin were used. Inoculated microplates were stored for 24 hours at $37^{\circ} \mathrm{C}$ and MIC values subsequently determined according to whether they were breeding in the wells $[18,19]$.

\subsection{Statistical Analysis}

All results were evaluated as an average of three parallel repetitions. Results were expressed as arithmetical mean \pm standard deviation. Error bars are indicated on the graphs. Independent Student's $\mathrm{t}$ test was used for pairwise comparisons and One- way ANOVA-Tukey HSD was used for multiple comparisons. The analysis was performed using SPSS 19.0.0 software.

\section{Results and Discussion}

\subsection{Extract Yield}

We determined that the extract yields of mushroom samples ranged from 2.67 to $4.45 \%$ for methanol and from 1.81 to $4.83 \%$ for ethanol (Table 1). As the mushroom samples are edible, they were used when fresh, in the form to be consumed and were not exposed to any drying process. Previous mushroom extract yields have been reported to be $1.5-4 \%[19,21]$ in one study, and $25-35 \%$ $[9,22]$ in another. The fact that the fresh mushroom species are rich in water affects extract yield. Additionally, 1 gram of fresh sample is not equal to 1 gram of dried sample in terms of matter content. In a study conducted with fresh mushroom samples, it was shown that the extract efficiency depends on species and differs from 1 to $16 \%$ [11]. These findings are consistent with the findings of this study.

When the mushroom sample extract yield percentages are compared, methanol and acetone extracts and the different mushroom species have shown statistically significant differences within themselves $(\mathrm{P}=<0.05)$.

Table 1. Yields of mushroom extracts by methanol and acetone * (\%)

\begin{tabular}{|c|c|c|}
\hline Mushroom Species & $\begin{array}{c}\text { Methanol Extracts } \\
\text { Yield (\%) }\end{array}$ & $\begin{array}{c}\text { Acetone Extracts } \\
\text { Yield (\%) }\end{array}$ \\
\hline B. edulis & $2.67 \pm 0.3$ & $1.81 \pm 0.01$ \\
\hline C. cibarius & $4.70 \pm 0.01$ & $4.83 \pm 0.08$ \\
\hline C. curnicopioides & $3.28 \pm 0.13$ & $1.90 \pm 0.03$ \\
\hline H. repandum & $4.45 \pm 0.01$ & $2.97 \pm 0.1$ \\
\hline A. bisporus & $4.27 \pm 0.11$ & $3.52 \pm 0.01$ \\
\hline
\end{tabular}

\section{2. $\beta$-glucan Content}

The highest $\beta$-glucan content from wild mushrooms was found in B. edulis $(13.93 \pm 0.78 \%)$. C. cibarius with the value of approximately $12.89 \pm 0.84 \%$ and $H$. repandum $(12.84 \pm 0.11 \%)$ were the next highest. The lowest 
$\beta$-glucan content was found in C. curnicopipides. A. bisporus (cultivated mushroom), which is cultivated on compost and used for commercial purposes, had the highest overall $\beta$-glucan content at $14.57 \pm 0.80 \%$. The difference in $\beta$-glucan content among the mushroom species was determined to be $(\mathrm{P}=<0.05)$ as shown in Figure 1.

Synytsya et al. (2008), have previously reported that dried Pleurotus mushroom contains between 32.5 and 50\% $\beta$-glucan when stem and stalk are analysed separately. While the $\beta$-glucan content of the stem is between 27.4-
$39.2 \%$, the content of the stalk part has been determined to be between $35.5-50.0 \%$ [12]. A study comparing the $\beta$-glucan content of Pleurotus abalonus, Pleurotus eous and Auricularia auricular species with long and short stalks, found values of $39.78 \%, 39.15 \%, 47.11 \%$ and $56.44 \%$ respectively [24]. In these studies and also this study were made with K-YBGL Kit (MEGAZYME), but Manzi and colleagues determined the $\beta$-glucan content of Pleurotus species to be $0.22-0.53 \mathrm{~g} / 100 \mathrm{~g}$ on dry basis with McCleary and Holmes method (1985) [23].

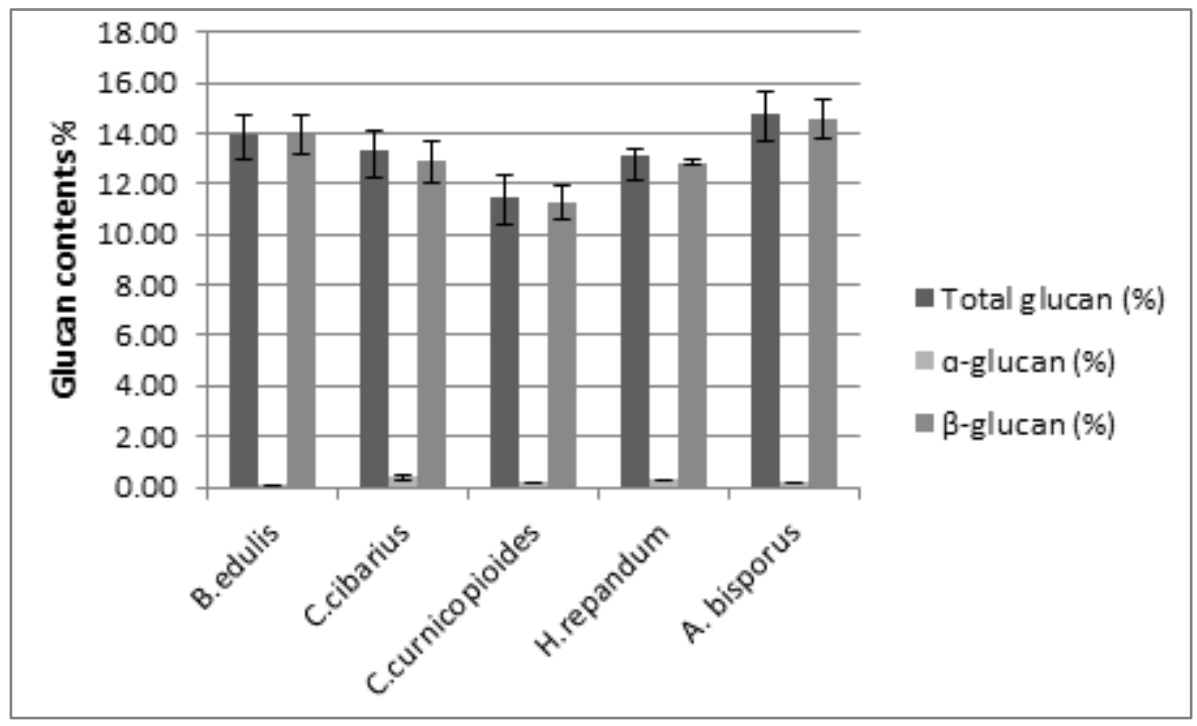

Figure 1. Glucan content of mushroom species (\%)

Table 2. Scavenging activities (\%) of DPPH radical of the methanol and acetone extracts of mushrooms at different concentrations a,b,c,d

\begin{tabular}{|c|c|c|c|c|c|c|}
\hline \multirow{2}{*}{ Mushroom species } & \multirow{2}{*}{ Solvent } & \multicolumn{5}{|c|}{ Extract Concentrations $(\mu \mathrm{g} \backslash \mathrm{ml})$} \\
\cline { 3 - 7 } & & 100 & 250 & 500 & 750 & 1000 \\
\hline \multirow{2}{*}{ B. edulis } & Methanol & $13.41 \pm 0.02 \mathrm{af}$ & $26.28 \pm 0.23 \mathrm{bf}$ & $42.76 \pm 0.26 \mathrm{cf}$ & $64.66 \pm 1.57 \mathrm{df}$ & $78.16 \pm 0.17 \mathrm{ef}$ \\
\cline { 2 - 7 } & Acetone & $10.15 \pm 0.02 \mathrm{af}$ & $16.20 \pm 0.27 \mathrm{bg}$ & $27.71 \pm 1.02 \mathrm{cg}$ & $43.19 \pm 0.99 \mathrm{dg}$ & $51.66 \pm 0.24 \mathrm{eg}$ \\
\hline \multirow{2}{*}{ C. cibarius } & Methanol & $4.06 \pm 0.42 \mathrm{af}$ & $4.94 \pm 0.03 \mathrm{af}$ & $4.42 \pm 0.48 \mathrm{af}$ & $9.10 \pm 0.14 \mathrm{af}$ & $9.20 \pm 0.19 \mathrm{af}$ \\
\cline { 2 - 7 } & Acetone & $0.46 \pm 0.66 \mathrm{af}$ & $1.64 \pm 0.63 \mathrm{af}$ & $5.59 \pm 1.38 \mathrm{ag}$ & $6.55 \pm 0.28 \mathrm{af}$ & $8.36 \pm 0.55 \mathrm{af}$ \\
\hline \multirow{2}{*}{ C. cornucopioides } & Methanol & $4.55 \pm 0.72 \mathrm{af}$ & $8.21 \pm 0.39 \mathrm{af}$ & $10.59 \pm 0.51 \mathrm{af}$ & $15.89 \pm 0.23 \mathrm{af}$ & $19.98 \pm 0.67 \mathrm{af}$ \\
\cline { 2 - 7 } & Acetone & $4.87 \pm 0.24 \mathrm{af}$ & $7.50 \pm 0.24 \mathrm{af}$ & $9.66 \pm 0.12 \mathrm{af}$ & $12.75 \pm 0.19 \mathrm{af}$ & $14.45 \pm 0.03 \mathrm{af}$ \\
\hline \multirow{2}{*}{ H. repandum } & Methanol & $3.41 \pm 0.14 \mathrm{af}$ & $4.29 \pm 1.24 \mathrm{af}$ & $4.82 \pm 0.35 \mathrm{af}$ & $5.83 \pm 0.06 \mathrm{af}$ & $5.43 \pm 0.39 \mathrm{af}$ \\
\cline { 2 - 7 } & Acetone & $3.56 \pm 0.19 \mathrm{af}$ & $3.84 \pm 0.20 \mathrm{af}$ & $4.32 \pm 0.38 \mathrm{af}$ & $5.38 \pm 0.30 \mathrm{af}$ & $6.15 \pm 0.06 \mathrm{af}$ \\
\hline \multirow{2}{*}{ A. bisporus } & Methanol & $9.41 \pm 0.35 \mathrm{af}$ & $19.39 \pm 0.37 \mathrm{bf}$ & $31.64 \pm 0.02 \mathrm{cf}$ & $50.78 \pm 0.19 \mathrm{df}$ & $60.53 \pm 0.43 \mathrm{ef}$ \\
\cline { 2 - 7 } & Acetone & $4.19 \pm 0.59 \mathrm{af}$ & $12.33 \pm 0.17 \mathrm{af}$ & $20.42 \pm 0.25 \mathrm{af}$ & $29.84 \pm 0.90 \mathrm{af}$ & $37.55 \pm 0.09 \mathrm{af}$ \\
\hline \multirow{2}{*}{ Standarts } & BHA & $95.42 \pm 0.56$ & $98.31 \pm 0$ & - & - & - \\
\cline { 2 - 7 } & BHT & $63.81 \pm 0$ & $73.55 \pm 0.22$ & - & - & - \\
\cline { 2 - 7 } & C vitamin & $95.80 \pm 0.52$ & $96.45 \pm 0$ & - & & - \\
\hline
\end{tabular}

a Values are means S.D. of triplicate measurement.

$\mathrm{b}$ Means in the same row with different letters (a-e) were significantly different $(\mathrm{P}<0.05)$ (One-way ANOVA-,Tukey-HSD)

c A statistically significant difference in concentration between each different fungal species were observed in the same column $(\mathrm{P}<0.05)(\mathrm{One}-\mathrm{way}$ ANOVA-,Tukey-HSD)

$\mathrm{d}$ Different letters in the same line (f-g) indicates that the effects of fungal species at different solvents is statistically significant $(\mathrm{P}<0.05)$ (Student T test)

e BHA, butylated hidroxyanisole

fBHT, butylated hidroxytoluene 
In this study, the DPPH radical scavenging activity of 1 $\mathrm{mg} / \mathrm{ml}$ of Boletus edulis was determined to be $78.16 \pm 0.17 \%$ in the methanol extract and $51.66 \pm 0.24 \%$ in the ethanol extract. The EC50 values of Boletus edulis methanol and ethanol extracts were 0.585 and $0.952 \mathrm{mg} / \mathrm{ml}$. Similarly, in the study of Sarıkürç̧ü et. al. the inhibition value of Boletus edulis methanol extract at the same concentration was $80.15 \pm 0.85 \%$ [25]. Keles et. al. determined the DPPH scavenging activity of $25 \mathrm{mg} / \mathrm{ml}$ of Boletus edulis dried sample methanol extract to be $93.18 \%$ [26]. In addition to this, the comparison between the extracts of fresh forms and dried forms of mushrooms has been stated to be inconsistent.

Kosanić et. al. determined the EC50 value of Boletus edulis to be 212.47 in a methanol extract and 4.72 in an acetone extract [27]. In another study, the EC50 value of Boletus edulis has been indicated to be $1.40 \pm 0.31$ [9].

The DPPH radical scavenging activity of Agaricus bisporus was determined to be $60.53 \pm 0.43 \%$ in the 1 $\mathrm{mg} / \mathrm{ml}$ methanol extract. In the study of Elmastaş et al., the DPPH radical scavenging activity of the $180 \mu \mathrm{g} / \mathrm{ml}$ methanol extract obtained from dried samples of cultivated mushroom was determined to be 77.5 [28]. Keleş et al. (2011), found DPPH radical scavenging activity of methanol extracts of dried samples of Agaricus bisporus at the concentration of $25 \mathrm{mg} / \mathrm{ml}$ to be $67.86 \%$ [26].

The EC50 value of cultivated mushrooms used in our study was calculated as $0.744 \mathrm{mg} / \mathrm{ml}$ for the methanol extract. In a similar study, the EC50 value of cultivated mushrooms was shown as $0.988 \pm 0.13 \mathrm{mg} / \mathrm{ml}$ [29].

In this study, the radical scavenging activity decreases between mushrooms as follows $C$. curnicopiodies $>C$. cibarius $>H$. repandum. The inhibition values of methanol and acetone extracts of the samples were similar. The findings of Keles et al. (2011) support the findings of this study; the inhibition value of DPPH radical scavenging activity of a methanol extract of Hydnum repandum was shown to be $10.17 \%$ (25 mg/ml) [26]. In another study, the EC50 value of Hydnum repandum was determined to be $14.50 \pm 0.38$ [9]. Heleno and colleagues found the EC50 value of Hydnum repandum to be $30 \pm 3.05$ [30] and the fact that Hydnum repandum has a low DPPH scavenging effect among the mushroom species has been supported in studies that parallel our findings. Liu et al. (2012) found no DPPH radical scavenging activity in Craterellus curnucopiodes [31]. It has been observed in the literature that there have not been enough studies regarding the antioxidant activity of C. curnucopiodes.

We found that there is a significant difference between the percentage inhibition values of the different concentrations of methanol and acetone extracts of $B$. edulis and A. bisporus $(\mathrm{P}=<0.05)$. At the same time, for each of the concentrations studied, there was a significant difference in the DPPH radical scavenging activity between the different mushroom species $(\mathrm{P}=<0.05)$. When methanol and acetone yields of each mushrooms were compared within themselves, there was a difference observed between the DPPH radical scavenging activity in $250,500,750,1000 \mu \mathrm{g} / \mathrm{ml}$ samples of $B$. edulis and in 500 $\mu \mathrm{g} / \mathrm{ml}$ sample of $C$. cibarius. The methanol and acetone extracts of other mushroom species have been observed to have similar activities.

\subsubsection{Total phenolic compounds}

Using the Folin-Ciocalteu Reactive method we found that that the phenolic compound contents of acetone extracts of the mushroom samples varied between $25.75 \pm$ $0.5-45.5 \pm 0.71 \mathrm{GAE} \mu \mathrm{g} / \mathrm{mg}$ and the phenolic contents of the methanol extracts varied between $22.75 \pm 1.08-41.25$ $\pm 0.42 \mathrm{GAE} \mu \mathrm{g} / \mathrm{mg}$. The phenolic contents of mushroom extracts decreased as follows: $B$. edulis $>A$. bisporus $>C$. curnicopioides $>H$. repandum. When the phenolic compounds of the mushrooms were compared, no significant difference was detected, even though a remarkable difference has been observed in B. edulis. Likewise, when phenolic compounds in the methanol and acetone extracts of mushroom species were compared, only in cultivated mushroom was there a significant difference between the methanol and acetone extracts $(\mathrm{P}=<0.05)$ (Table 3).

Table 3. Yield of phenolics ( $\mathrm{mg}$ of GAEsa $\mu \mathrm{g} / \mathrm{mg}$ ) in different mushrooms obtained by different solvents b,c,d $(\mathrm{P}<0.05)$

\begin{tabular}{|c|c|c|}
\hline \multirow{2}{*}{ Mushroom Species } & \multicolumn{2}{|c|}{ Concentrations $\mu \mathrm{g} / \mathrm{mg}$} \\
\cline { 2 - 3 } & Methanol Extract & Acetone Extract \\
\hline B. edulis & $41.3 \pm 0.42 \mathrm{ac}$ & $45.5 \pm 0.71 \mathrm{ac}$ \\
\hline C. cibarius & $25.75 \pm 1.06 \mathrm{bc}$ & $26.25 \pm 0.35 \mathrm{bc}$ \\
\hline C. curnicopioides & $26.3 \pm 0.28 \mathrm{bc}$ & $27.75 \pm 1.13 \mathrm{bc}$ \\
\hline H. repandum & $22.75 \pm 0.32 \mathrm{bc}$ & $25.75 \pm 0.50 \mathrm{bc}$ \\
\hline A. bisporus & $34 \pm 0.71 \mathrm{bc}$ & $30 \pm 0 \mathrm{bd}$ \\
\hline
\end{tabular}

a GAEs, gallic acid equivalents

b Values are means S.D. of triplicate measurement.

c Different letters $(\mathrm{a}, \mathrm{b})$ in the same column and row represents a statistically significant difference in the amount of phenolics between mushroom species $(\mathrm{P}<0.05)$ (One-way ANOVA-,Tukey-HSD)

$\mathrm{d}$ Different letters in the same line $(\mathrm{c}, \mathrm{d})$ indicates it is statistically significant that the amount of phenolic compounds in different solvents mushroom species $(\mathrm{P}<0.05)$ (Student $\mathrm{T}$ test)

The extracts with highest phenolic compound content between the studied mushroom species were the acetone extract $(45.5 \pm 0.71 \mu \mathrm{g} / \mathrm{mg})$ of $B$. edulis and methanol extract $(41.25 \pm 0.42 \mu \mathrm{g} / \mathrm{mg})$ of $B$. edulis. The phenolic contents of the methanol extracts of B. edulis, H. repandum and $C$. cibarius species have been previously reported as $8.4 \mathrm{mg} / \mathrm{g}, 2.6 \mathrm{mg} / \mathrm{g}$ and $2.8 \mathrm{mg} / \mathrm{g}$ by the same method but with dried mushrooms [9]. The total phenolic content of an acetone extract of $B$. edulis has been calculated as $8.14 \pm$ $1.211 \mu \mathrm{g} / \mathrm{mg}$ and the total phenolic content of a methanol extract of $B$. edulis has been calculated as $4.64 \pm 1.318$ $\mu \mathrm{g} / \mathrm{mg}$ of pyrocatechol equivalent according to Kosanić et al. [27]. In the study of Sarıkürkçü et al., the total phenolic contents of a methanol extract of $B$. edulis were observed to 
be $31.64 \pm 0.55 \mu \mathrm{g} / \mathrm{mg}$ with the same method and dried mushrooms [25]. The total phenolic content of dries $B$. edulis was reported as $12.775 \mathrm{mg} / \mathrm{g} \mathrm{[26].}$

In this study, the total phenolic content of the methanol extract of C. cibarius was $25.75 \pm 1.06 \mu \mathrm{g} / \mathrm{mg}$. In the study of Ramesh et. al. , the total phenolic contents of a methanol extract of C. cibarius were $3.20 \pm 0.05 \mathrm{mg} / \mathrm{g}$ [32]. In the study, the total phenolic content of a methanol extract of $C$. cibarius was $0.74 \pm 0.15 \mu \mathrm{g} / \mathrm{mg}$ [31]. The total phenolic content of a methanol extract of Hydnum repandum was measured as $22.75 \pm 0.32 \mu \mathrm{g} / \mathrm{mg}$. In the study of Heleno et al., the phenolic content of $H$. repandum mushroom was found to be $0.51 \pm 0.02 \mathrm{mg} / \mathrm{g}$ [30].

When the DPPH radical scavenging and total phenolic contents of the studied mushroom samples were compared, $B$. edulis and A. bisporus had the higher values than the other samples in both methanol and acetone extracts.

\subsubsection{Reducing power capacity}

When the reducing power of mushroom samples was compared with the standards, $1 \mathrm{mg} / \mathrm{ml}$ samples had lower values than the $100 \mu \mathrm{g} / \mathrm{ml}$ standards (Table 4). Taking these data into consideration, reducing power was observed in the studied mushroom samples. These results concur with similar studies of the same mushrooms from this region, and other countries [9, 22, 27, 33].

Previous studies of mushroom species dried at $40^{\circ} \mathrm{C}$ and frozen, found that the antioxidant levels had increased; whereas, in boiled samples, the levels decreased [34]. When the reducing power capacities of mushrooms were compared here, there was no significant difference observed $(\mathrm{P}=<0.05)$ (Table 4).

With the mushroom species used in our study and several other species such as Pleurotus, Schizophyllum, Lentinus, Termitomyces, Geastrum species etc., activity studies have been conducted that found antioxidant activities at different ratios depending on the concentration, species and solution type used for the extract preparation $[35,36]$.

Table 4. Reducing power capacities in different mushrooms obtained by different solvents b,c,d,e $(700 \mathrm{~nm})$

\begin{tabular}{|c|c|c|c|c|c|c|}
\hline \multirow{2}{*}{ Mushroom species } & \multirow{2}{*}{ Solvent } & \multicolumn{5}{|c|}{ Concentrations $(\mu \mathrm{g} / \mathrm{ml})$} \\
\hline & & 100 & 250 & 500 & 750 & 1000 \\
\hline \multirow{2}{*}{ B. edulis } & Methanol & $0.81 \pm 0.07$ & $0.79 \pm 0.11$ & $0.84 \pm 0.20$ & $0.82 \pm 0.31$ & $0.86 \pm 0.39$ \\
\hline & Acetone & $0.82 \pm 0.13$ & $0.84 \pm 0.22$ & $0.85 \pm 0.28$ & $0.80 \pm 0.40$ & $0.81 \pm 0.47$ \\
\hline \multirow{2}{*}{ C. cibarius } & Methanol & $0.77 \pm 0.07$ & $0.83 \pm 0.10$ & $0.84 \pm 0.09$ & $0.82 \pm 0.10$ & $0.84 \pm 0.10$ \\
\hline & Acetone & $0.79 \pm 0.06$ & $0.74 \pm 0.06$ & $0.81 \pm 0.07$ & $0.80 \pm 0.07$ & $0.83 \pm 0.11$ \\
\hline \multirow{2}{*}{ C. cornucopioides } & Methanol & $0.82 \pm 0.09$ & $0.82 \pm 0.09$ & $0.83 \pm 0.09$ & $0.82 \pm 0.12$ & $0.82 \pm 0.13$ \\
\hline & Acetone & $0.93 \pm 0.27$ & $0.87 \pm 0.19$ & $0.88 \pm 0.17$ & $0.86 \pm 0.16$ & $0.84 \pm 0.14$ \\
\hline \multirow{2}{*}{ H. repandum } & Methanol & $0.82 \pm 0.09$ & $0.85 \pm 0.14$ & $0.85 \pm 0.11$ & $0.85 \pm 0.13$ & $0.82 \pm 0.07$ \\
\hline & Acetone & $0.87 \pm 0.22$ & $0.95 \pm 0.30$ & $0.79 \pm 0.06$ & $0.80 \pm 0.06$ & $0.81 \pm 0.08$ \\
\hline \multirow{2}{*}{ A. bisporus } & Methanol & $1.11 \pm 0.16$ & $1.02 \pm 0.28$ & $1.11 \pm 0.10$ & $1.12 \pm 0.03$ & $1.12 \pm 0.03$ \\
\hline & Acetone & $0.81 \pm 0.07$ & $0.79 \pm 0.11$ & $0.84 \pm 0.20$ & $0.82 \pm 0.31$ & $0.86 \pm 0.39$ \\
\hline \multirow{3}{*}{ Standarts } & BHA & $1.82 \pm 0.01$ & - & - & - & - \\
\hline & BHT & $1.72 \pm 0.03$ & - & - & - & - \\
\hline & $\mathrm{C}$ vitamin & $1.70 \pm 0.01$ & - & - & - & - \\
\hline
\end{tabular}

a Absorbance

b Values are means S.D. of triplicate measurement.

c A statistically significant difference between different concentrations of each mushroom species weren't observed on the same line $(\mathrm{P}>0.05)$ (one-way ANOVA-Tukey-HSD)

$\mathrm{d}$ A statistically significant difference between different concentrations of each mushroom species weren't observed on the same coloumn (P > 0.05) (one-way ANOVA-Tukey-HSD)

e A statistically significant difference between different solvents of each mushroom species weren't observed on the same line. (P $>0.05)($ Student T test) 


\subsection{Guaiacol Peroxidase Activity}

Peroxidases are an important enzyme group, having antioxidant effects and being found in plants, mushrooms and vertebrates. Guaiacol peroxidases are a group of the peroxidase enzyme family that use guaiacol as a substrate [37].

Guaiacol peroxidase activity with an antioxidant effect has been found in Boletus edulis and Agaricus bisporus. However, in the other mushroom species no guaiacol peroxidase enzyme activity has been detected. According to this studies results, the enzyme activities of Boletus edulis and Agaricus bisporus are 0.07 and $0.13 \mathrm{U} / \mathrm{ml}$. Furthermore, in a study of Cantharellus cibarius and Pleurotus eryngii, observed guaiacol peroxidase activity in Cantharellus mushrooms at $0.011 \pm 0.001 \mathrm{U} / \mathrm{mg}$ [38].

\subsection{Antimicrobial Activity}

In this study, the antimicrobial effects of Boletus edulis, Cantharellus cibarius, Craterellus cornucopiodies, Hydnum repandum and Agaricus bisporus on hospital isolates and standard strains: Gram-positive bacteria; Staphylococcus aureus, Enterecoccus faecalis as well as Gram-negative bacteria; Escherichia coli, Enterobacter cloacae, Klebsiella pneumoniae, Serratia marcescens and Pseudomonas aeruginosa were searched. Using the methanol and acetone extracts obtained from mushroom samples, agar disk diffusion and micro-dilution methods were implemented. We found that different concentrations of mushroom extracts had antimicrobial effects on several bacteria at different ratios (Table 5).

According to the experiment results, the $200 \mathrm{mg} / \mathrm{ml}$ concentration of $B$. edulis methanol extract produced a 15 $\mathrm{mm}$ zone of inhibition over $S$. aureus bacteria. For this bacterium, the microdilution method revealed a MIC greater than $2 \mathrm{mg} / \mathrm{ml}$. The MIC value of the acetone extract of Boletus edulis was $2 \mathrm{mg} / \mathrm{ml}$ for E. coli 25922. In a study conducted by Kosanić et al. (2012), The MIC value of an acetone extract of Boletus edulis was $5 \mathrm{mg} / \mathrm{ml}$ for E. coli. In another study, the same mushroom was found to have an inhibitory effect on Actinomyces viscosus and Staphylococcus aureus bacteria replication at 50-100 $\mathrm{mg} / \mathrm{ml}$ concentrations [39].

An $8 \mathrm{~mm}$ zone of inhibition over $S$. aureus bacteria was produced by the Cratarellus cornicopioides acetone extract. The methanol extract produced a $15 \mathrm{~mm}$ zone of inhibition on $K$. pneumoniae. The MIC value for $S$. aureus was 2 $\mathrm{mg} / \mathrm{ml}$ and for K. pneumoniae was greater than $2 \mathrm{mg} / \mathrm{ml}$.

The methanol and acetone extracts of Cantharellus cibarius, particularly the $200 \mathrm{mg} / \mathrm{ml}$ samples generated 10 $\mathrm{mm}$ and $14 \mathrm{~mm}$ zones of inhibition for $S$. aureus and $S$. marcescens bacteria. The MIC value for $S$. aureus was 2 $\mathrm{mg} / \mathrm{ml}$ and for $S$. marcescens, it was greater than $2 \mathrm{mg} / \mathrm{ml}$. Previous studies of Cratarellus cornicopioides found that methanol and acetone extracts had antimicrobial effects on several varieties of bacteria $[32,33,39,40]$.

The zone of inhibition produced by the methanol and acetone extracts of $H$. repandum generated for $S$. aureus, $E$. faecalis and $P$. aeruginosa was between $8-15 \mathrm{~mm}$. The MIC values of the extracts was $>2 \mathrm{mg} / \mathrm{ml}$ for $E$. faecalis and $P$. aeruginosa and $0.5 \mathrm{mg} / \mathrm{ml}$ for $S$. aureus. In previous studies, $H$. repandum extracts produced a zone of inhibition less than $10 \mathrm{~mm}$ for these bacteria as well as $50-100 \mathrm{mg} / \mathrm{ml}$ MIC values [9, 39].

Agaricus bisporus has been shown to have antimicrobial activity against $P$. aeruginosa bacteria, producing a zone of inhibition of 9-12 $\mathrm{mm}$. The MIC values observed were $>2$ $\mathrm{mg} / \mathrm{ml}$. In the other antimicrobial activity studies conducted with cultivated mushrooms, different extracts generated zones of inhibition between 15 and $24 \mathrm{~mm}$ for the bacteria tested $[2,39]$.

Table 5. Mushroom species that have antimicrobial activities at different test microorganisms a,b,c,d

\begin{tabular}{|c|c|c|c|c|c|c|c|c|c|c|c|}
\hline \multirow{2}{*}{$\begin{array}{l}\text { Mushroom } \\
\text { species }\end{array}$} & \multirow{2}{*}{$\begin{array}{c}\text { Test } \\
\text { microorganisms } \\
\text { (clinical isolates) }\end{array}$} & \multicolumn{3}{|c|}{ Methanol extracts } & \multicolumn{3}{|c|}{ Acetone extracts } & \multicolumn{3}{|c|}{ Positive control } & \multirow{2}{*}{$\begin{array}{c}\text { Negative } \\
\text { Control } \\
\text { (DMSO) } \\
\end{array}$} \\
\hline & & $50 \mathrm{mg} \backslash \mathrm{ml}$ & $100 \mathrm{mg} \backslash \mathrm{ml}$ & $200 \mathrm{mg} \backslash \mathrm{ml}$ & $50 \mathrm{mg} \backslash \mathrm{ml}$ & $\begin{array}{c}100 \\
\mathrm{mg} \backslash \mathrm{ml}\end{array}$ & $\begin{array}{c}200 \\
\mathrm{mg} \backslash \mathrm{ml}\end{array}$ & $\begin{array}{c}\text { Amp } \\
(10 \mu \mathrm{g})\end{array}$ & $\begin{array}{c}\text { Clo } \\
(10 \mu \mathrm{g})\end{array}$ & Ofl $(5 \mu \mathrm{g})$ & \\
\hline $\begin{array}{c}\text { Cantharellus } \\
\text { cibarius }\end{array}$ & $\begin{array}{c}\text { S.aureus } \\
\text { S.marcenses }\end{array}$ & $\begin{array}{l}- \\
-\end{array}$ & $\begin{array}{l}8 \\
- \\
\end{array}$ & $\begin{array}{l}10 \\
12 \\
\end{array}$ & - & $\begin{array}{l}10 \\
10\end{array}$ & $\begin{array}{l}12 \\
14\end{array}$ & $\begin{array}{l}19 \\
23\end{array}$ & $\begin{array}{l}28 \\
26\end{array}$ & $\begin{array}{l}27 \\
28 \\
\end{array}$ & - \\
\hline Boletus edulis & S.aureus & - & - & 15 & - & - & - & 20 & 28 & 29 & - \\
\hline $\begin{array}{c}\text { Craterellus } \\
\text { cornucopioides }\end{array}$ & K.pneumoniae & - & - & 15 & - & - & 15 & 10 & 30 & 30 & - \\
\hline $\begin{array}{l}\text { Hydnum } \\
\text { repandum }\end{array}$ & $\begin{array}{c}\text { S.aureus } \\
\text { E.facealis } \\
\text { S.marcenses } \\
\text { P.aeruginosa }\end{array}$ & $\begin{array}{l}- \\
- \\
- \\
-\end{array}$ & $\begin{array}{l}15 \\
- \\
- \\
-\end{array}$ & $\begin{array}{c}15 \\
10 \\
- \\
10 \\
\end{array}$ & $\begin{array}{l}14 \\
- \\
8 \\
- \\
\end{array}$ & $\begin{array}{c}14 \\
8 \\
10 \\
- \\
\end{array}$ & $\begin{array}{l}15 \\
10 \\
12 \\
14 \\
\end{array}$ & $\begin{array}{r}20 \\
26 \\
26 \\
- \\
\end{array}$ & $\begin{array}{l}27 \\
22 \\
29 \\
20 \\
\end{array}$ & $\begin{array}{l}27 \\
20 \\
28 \\
- \\
\end{array}$ & $\begin{array}{l}- \\
- \\
- \\
-\end{array}$ \\
\hline $\begin{array}{l}\text { Agaricus } \\
\text { bisporus }\end{array}$ & P.aeruginosa & - & 9 & 9 & - & 10 & 12 & - & 15 & - & - \\
\hline
\end{tabular}

a Amp, Ampicilin

b Ofl, Ofloxacin

c Clo, Chloramphenicol

d DMSO, dimethyl sulfoxide

(-), Not detected 


\section{Conclusions}

In this study we determined the antimicrobial activities, antioxidant activities and $\beta$-glucan content of four different edible wild mushroom species that grow naturally and a cultured mushroom. Based on the results, we suggest that these wild mushroom species are consumed more as a food source and their extracts should be used as an alternative treatment method. As the mushroom samples are edible, they were used when fresh, in the form to be consumed and were not exposed to any drying process. From this point of view, this study can be regarded as a first and it will be able to shed light on future studies. Therefore, further work can be the investigation of anti-cancerogenic effects of these mushroom extracts in cell culture studies in different cancer cell lines.

\section{Acknowledgements}

The study was supported by Trakya University Scientific Research Fund, project no: 2013/02.

\section{REFERENCES}

[1] P. Manzi, L. Gambelli, S. Marconi, V. Vivanti, L. Pizzoferrato. Nutrients in edible mushrooms: an inter-species comparative study, Food chemistry, Vol.65, 477-482, 1999.

[2] Ch. Surekha, DSVGK. Kaladhar, J. R. Raju Srikakarlapud Haseena. Evaluation of antioxidant and antimicrobial potentiality of some edible mushrooms, International Journal of Advanced Biotechnology and Research, Vol.2, 130-134, 2011.

[3] E. Pereira, L. Barros, A. Martins, I. C. Ferreira. Towards chemical and nutritional inventory of Portuguese wild edible mushrooms in different habitats, Food Chemistry, Vol. 130, 394-403, 2012.

[4] K. A. Hillaimaharani, K. Sharmila, P. Thangaraju, M. Karthick, M. Kalaiselvam. Studies on antimicrobial and antioxidant properties of oyster mushroom Pleurotus florida, Journal of Pharmaceutical Sciences and Research, Vol.4, 1540-1545, 2013.

[5] R. Duman, H. Taner, H. H. Doğan. Antimicrobial activities of some macrofungus, Afyon Kocatepe University Journal of Science, Vol.7, No.1, 55-65, 2007 (In Turkish)

[6] M. Yamaç, F. Bilgili. Antimicrobial activities of fruit bodies and/or mycelial cultures of some mushroom isolates, Pharmaceutical Biology, Vol.44, 660-667, 2006.

[7] S. Rahar, G. Swami, N. Nagpal, M. A. Nagpal, G. S. Singh. Preparation, characterization, and biological properties of $\beta$-glucans, Journal of Advanced Pharmaceutical Technology and Research, Vol.2, 94-103, 2011.

[8] I. Y. Bae, H. W. Kim, H. J. Yoo, E. S. Kim, S. Lee, D. Y. Park, H. G. Lee. Correlation of branching structure of mushroom $\beta$-glucan with its physiological activities, Food Research International, Vol.51, 195-200, 2013.

[9] N. G. Puttaraju, S. U. Venkateshaiah, S. M. Dharmesh. Antioxidant activity of indigenous edible mushrooms. Journal of Agricultural and Food Chemistry, Vol.54, 9764-9772, 2006.

[10] M. Akyuz, A. N. Onganer. Antimicrobial activity of some edible mushrooms in the eastern and southeast Anatolia region of Turkey. Gazi University Journal of Science, Vol.23, No.2, 125-130, 2010

[11] J. Y. Wong, F. Y. Chye. Antioxidant properties of selected tropical wild edible mushrooms, Journal of Food Composition and Analysis, Vol.22, 269-277, 2009.

[12] A. Synytsya, K. Míčková, I. Jablonský, M. Slukocaá, J. Čopíková. Mushrooms of genus Pleurotus as a source of dietary fibres and glucans for food supplements, Czech Journal of. Food Sciences, Vol.26, 441-446, 2008.

[13] M. S. Blois. Antioxidant determinations by the use of a stable free radical, Nature, Vol.181, 1199-1200, 1958.

[14] S. C. Litescu, S. Eremia, Radu. Methods for the determination of antioxidant capacity in food and raw materials, Advances in Experimental Medicine and Biology, Vol.698, 2010.

[15] V. L. Singleton, J. A. Rossi. Colorimetry of total phenolics with phosphomolybdic-phosphotungstic acid reagents, American Journal of Enology and Viticulture, Vol.16, $144-158,1965$

[16] M. Oyaizu. Studies on products of browning reaction antioxidative activities of products of browning reaction prepared from glucosamine, Japanese Journal of Nutrition, Vol.44, 307-315, 1968.

[17] H. P. Singh, D. R. Batish, R. K.Kohli, K.Arora Arsenic-induced root growth inhibition in mung bean (Phaseolus aureus Roxb.) is due to oxidative stress resulting from enhanced lipid peroxidation, Plant Growth Regulation, 53, 65-73, 2007.

[18] Clinical and Laboratory Standards Institute (CLSI) (formerly NCCLS), Performance Standards for Antimicrobial Susceptibility Testing 8th Informational Supplement. CLSI M100-S18, Clinical and Laboratory Standards Institute, 940 West Valley Road, Wayne, Pennsylvania, USA, 2008.

[19] Clinical and Laboratory Standards Institute (CLSI) (formerly NCCLS), Reference Method for Broth Dilution Antifungal Susceptibility Testing of Yeast Approved Standard, M27-A3, Clinical and Laboratory Standards Institute, 940 West Valley Road, Wayne, Pennsylvania, USA, 2006.

[20] P. Bobek, L. Ozdín, Š. Galbavý. Dose-and time-dependent hypocholesterolemic effect of oyster mushroom (Pleurotus ostreatus) in rats, Nutrition, Vol.14, 282-286, 1998.

[21] N. Ejikeme, O. U. Henrietta. Antimicrobial activity of some local mushrooms on pathogenic isolates, Journal of Medicinal Plants Research, Vol.4, No:23, 2011.

[22] C. Sarıürkçü,: Determination of the antioxidant activity of some edible mushrooms in the Mediterranean, $\mathrm{PhD}$. Thesis, Süleyman Demirel University Institute of Science, Isparta, 
Turkiye, 2009. (In Turkish)

[23] P. Manzi, L. Pizzoferrato. Beta-glucans in edible mushrooms, Food Chemistry, 68, 315-318, 2000.

[24] T. Inyod, S. Piamvaree, S. Jamjumroon, V. Sasomsaup, S. Verasathiean, S. Sungkarn. A $\beta$-glucan from short and long-stalked Pleurotus abalonus Han, Pleurotus eous and Auricularia auricula (Hook.) Underw, Agricultural Science Journal, Vol. 42, 650-652, 2011.

[25] C. Sarikurkcu, B. Tepe, M. Yamaç. Evaluation of the antioxidant activity of four edible mushrooms from the Central Anatolia, Eskisehir-Turkey: Lactarius deterrimus, Suillus collitinus, Boletus edulis, Xerocomus chrysenteron, Bioresource Technology, Vol.99, No.14, 6651-6655, 2008.

[26] A. Keleş, İ. Koca, H. Gençcelep. Antioxidant properties of wild edible mushrooms, Journal of Food Processing and Technology, Vol.2, 6, 2011.

[27] M. Kosanić, B. Ranković, M. Dašić. Mushrooms as possible antioxidant and antimicrobial agents, Iranian Journal of Pharmaceutical Research, Vol.11, No.4, 1095-1102, 2012.

[28] M. Elmastas, O. Isildak, I. Turkekul, N. Temur. Determination of antioxidant activity and antioxidant compounds in wild edible mushrooms, Journal of Food Composition and Analysis, Vol.20, No.3, 337-345, 2007.

[29] M. Öztürk, M. E. Duru, Ş. Kivrak, N. Mercan-Doğan, A. Türkoglu, M. A. Özler. In vitro antioxidant, anticholinesterase and antimicrobial activity studies on three Agaricus species with fatty acid compositions and iron contents: A comparative study on the three most edible mushrooms, Food and Chemical Toxicology, Vol.49, No.6, 1353-1360, 2011.

[30] S. A. Heleno, L. Barros, M. J. Sousa, A. Martins, I. C.Ferreira. Tocopherols composition of Portuguese wild mushrooms with antioxidant capacity, Food Chemistry, Vol.119, No.4, 1443-1450, 2010.

[31] Y. T. Liu, J. Sun, Z. Y. Luo, S. Q. Rao, Y. J. Su, R. R. Xu, Y. J. Yang. Chemical composition of five wild edible mushrooms collected from Southwest China and their antihyperglycemic and antioxidant activity, Food and Chemical Toxicology, Vol.50, No.5, 1238-1244, 2012.

[32] C. Ramesh, M. G. Pattar. Antimicrobial properties, antioxidant activity and bioactive compounds from six wild edible mushrooms of western ghats of Karnataka, India, Pharmacognosy research, Vol.2, No.2, 107-112, 2010.

[33] M. Kosanic, B. Rankovic, M. Dasic. Antioxidant and antimicrobial properties of mushrooms, Bulgarian Journal of Agricultural Science, Vol.19, No.5, 1040-1046, 2013.

[34] L. Barros, S. Falcão, P. Baptista, C. Freire, M. Vilas-Boas, I. C. Ferreira. Antioxidant activity of Agaricus sp. mushrooms by chemical, biochemical and electrochemical assays, Food chemistry, Vol.111, No.1, 61-66, 2008.

[35] A. Z. Woldegiorgis, D. Abate, G. D. Haki, G. R. Ziegler. Antioxidant property of edible mushrooms collected from Ethiopia, Food Chemistry, Vol.157, 30-36, 2014.

[36] H. H. Arbaayah, Y. U. Kalsom. Antioxidant properties in the Oyster mushrooms (Pleurotus spp.) and split gill mushroom (Schizophyllum commune) ethanolic extracts, Mycosphere, Vol.4, 661-673, 2013.

[37] L. Ghamsari, E. Keyhani, S. Golkhoo. Kinetics properties of guaiacol peroxidase activity in Crocus sativus L. corm during rooting, Iranian Biomedical Journal, Vol.11, No.3, 137-146, 2007.

[38] J. Keyhani, E. Keyhani, Anti-oxidative stress enzymes in golden chanterelle (Cantharellus cibarius), Microbes in Applied Research: Current Advances and Challenges, Vol.23, 21-27, 2012.

[39] M. J. Alves, I. C. Ferreira, J. Dias, V. Teixeira, A. Martins, M. Pintado. A review on antimicrobial activity of mushroom (Basidiomycetes) extracts and isolated compounds, Planta Medica, Vol.78, No.16, 1707-1718, 2012.

[40] D. A. Aina, S. G. Jonathan, O. J. Olawuyi, D. O. Ojelabi, B. M. Durowoju. Antioxidant, antimicrobial and phytochemical properties of alcoholic extracts of Cantharellus cibarius-a Nigerian mushroom. New York Science Journal, Vol.5, No.10, 114-120, 2012. 